\title{
ASPECTOS POLÊMICOS DA CONCRETIZAÇÃO DO DIREITO À SAÚDE EM FACE DAS AÇÕES JUDICIAIS PARA FORNECIMENTO DE MEDICAMENTOS NO BRASIL
}

\author{
CONTROVERSIAL ASPECTS OF IMPLEMENTATION \\ OF THE RIGHT TO HEALTH IN FACE OF LAWSUITS \\ FOR SUPPLY OF DRUGS IN BRAZIL
}

\author{
AURÉLIA CARLA QUEIROGA DA SILVA ${ }^{1}$ \\ GABRIELA GALIZA E SILVA ${ }^{2}$
}

\begin{abstract}
RESUMO: O constitucionalismo pátrio avoca o Princípio da Dignidade Humana como um dos fundamentos da República Federativa do Brasil, de modo que ao Estado surge o dever de se abster, ou seja, de adotar uma postura negativa em face dos direitos de liberdade, ao passo que reclama por uma intervenção estatal direta e positiva, através da prestação de serviços públicos, a fim de assegurar o exercício dos Direitos Sociais. O presente estudo abordará, através do método dedutivo, pautado na análise da doutrina abalizada e da jurisprudência, o fenômeno conhecido por judicialização da saúde com o escopo de avaliar criticamente o impacto do ativismo judicial, sobretudo, no que se refere às decisões do STF quanto ao fornecimento de medicamentos. Destarte, a judicialização não pode vir a representar uma afronta ao Princípio da Separação dos Poderes, influindo negativamente na implantação e desenvolvimento de Políticas Públicas, todavia, se reconhece o papel legítimo atribuído ao Judiciário de efetivar os Direitos Fundamentais, notadamente o Direito à Saúde, quando da omissão dos demais Poderes constituídos nos quadros do Estado Constitucional Democrático.

PALAVRAS-CHAVE: Direito à Saúde; Medicamentos; Judicialização; Dignidade Humana.
\end{abstract}

Artigo recebido em 06.02.2015. Pareceres emitidos em 13.04.2015, 30.04.2015 e 30.07.2015.

Artigo aceito para publicação em 30.10.2015.

${ }^{1}$ Mestre em Direito pelo Programa de Pós-Graduação da Universidade Federal do Rio Grande do Norte - UFRN (Natal/RN). Especialista em Direito Processual Civil pela Universidade Federal de Campina Grande - UFCG (Sousa/PB). Professora de Direito Civil e da Área Propedêutica pela Universidade do Estado do Rio Grande do Norte - UERN (Natal/RN). aureliacarla@yahoo.com.br

${ }^{2}$ Bacharel em Direito pela Universidade do Estado do Rio Grande do Norte - UERN (Natal/RN). Assistente Técnica em Saúde pela Secretaria de Saúde Pública do Estado do Rio Grande do Norte. Advogada (OAB/RN).gabrielagaliza.adv@gmail.com 
ABSTRACT: Brazilian Constitutionalism evokes the Principle of Human Dignity as one of the cornerstones of the Federative Republic of Brazil. Thefore, in one hand, for the State arises the duty of abstentionism, in other words, it has to adopt a negative attitude vis-à-vis the freedom right of each individual. While on the other hand, it has to claim a direct and positive intervention, through the provision of public services in order to guarantee Social Rights. The present study will address, through deductive method, based on the analysis of authoritative doctrine and jurisprudence of the country, the phenomenon known as legalization of health with the aim of critically assess the impact of judicial activism, particularly with regard to decisions the Supreme Court regarding the supply of medicines. Hence, judicialization cannot come to represent an outrage to the principle of Separation of Powers, which would negatively influence the implementation of public policy. Otherwise, it's recognized that the judiciary has a legitimate role in enforcing the Fundamental Rights, notedly the Right of Healthcare, in order to circumvent the omission of the other Powers in na Democratic Constitutional State.

KEYWORDS: Right of Health; Drugs; Judicialization; Human Dignity.

SUMÁRIO: Introdução; 1. O Postulado da Reserva do Possível e a Proteção ao Mínimo Existencial no Âmbito da Saúde; 2. O Ativismo Judicial e a Busca da Celeridade quanto à Prestação dos Serviços de Saúde Pública na Seara do Fornecimento de Medicamentos; 3. As Tutelas Individuais de Urgência na Concessão de Medicamentos por Via Judicial: o embate entre o direito à vida e a salvaguarda da saúde coletiva; 4. A Jurisprudência do STF em Face ao Dever de Aplicação Imediata do Direito à Saúde no Brasil e os Limites à Concessão das Tutelas Individuais de Urgência quanto a Medicamentos; Conclusão; Referências.

CONTENTS: Introduction; 1 . The Postulate of Possible Reserves and the Protection of the Existential Minimum in Health; 2. The Judicial Activism and the Pursuit of Speed in the Provision of Public Health Services in the Harvest of Medications Supply; 3. Individual Emergency Guardianships in Providing Medicines Through the Courts: the clash between the right to life and the protection of public health; 4. The Jurisprudence of the Supreme Court in Relation to the Immediate Application of the Duty of the Right to Health in Brazil and Limits the Granting of Individual Emergency Guardianships as Medications; Conclusion; References.

\section{INTRODUÇÃO}

Ao enveredar na órbita do Constitucionalismo pátrio, percebe-se que a dignidade da pessoa humana figura como um dos fundamentos da República Federativa do Brasil. Como princípio, revela-se verdadeiro epicentro da ordem jurídica brasileira, em torno do qual gravitam os demais direitos fundamentais, impondo ao Estado o dever de se abster, ou seja, de adotar uma postura negativa em face dos direitos de liberdade, ao passo que reclama por uma intervenção estatal direta e positiva, através da prestação de serviços públicos, a fim de assegurar o exercício dos direitos sociais. Nesse sentido, a Constituição vigente exsurge-se concatenada com a ordem internacional seguida pelos países europeus, que na contemporaneidade, denotam tratamento especial aos Direitos e Garantias Fundamentais.

No contexto de um Estado Constitucional Democrático ${ }^{3}$, em que os direitos

\footnotetext{
${ }^{3}$ A reconstitucionalização da Europa, imediatamente após a $2^{\mathrm{a}}$ Grande Guerra e ao longo da segunda metade do século $X X$, redefiniu o lugar da Constituição e a influência do direito constitucional sobre
} 
fundamentais exercem a centralidade na órbita constitucional, posto gozarem da prerrogativa de aplicabilidade imediata e direta pelo Poder Judiciário, surge o debate acerca da concretização desses direitos, particularmente do direito à saúde, em face do crescimento exponencial das ações judiciais que pretendem a condenação dos entes federados ao fornecimento de medicamentos e/ou ao custeio de tratamentos médico-hospitalares. Tais pretensões põem em discussão se toda e qualquer prestação de saúde deve ser assegurada pelo Poder Público, mesmo que despida do caráter de essencialidade, ou até mesmo quando se refira a tratamentos experimentais ou a medicamentos que ainda não possuam registro na Agência Nacional de Vigilância Sanitária (ANVISA).

Nesse desiderato, o estudo que se segue procura tecer uma análise crítica sobre o papel que vem sendo exercido pelos juízes e tribunais pátrios na concretização do direito fundamental à saúde, sobretudo, no que tange ao fornecimento individual de medicamentos e o impacto provocado pelo fenômeno do ativismo quanto às decisões do STF no Brasil.

Depreende-se que, embora a intervenção do Judiciário na seara da saúde, através da multiplicação de provimentos que condenam a Administração Pública ao fornecimento de medicamentos, materiais e outros procedimentos médico-hospitalares, possa fazer parecer ser a efetivação do direito constitucional que garante o acesso universal e integral aos serviços dessa natureza, tal fenômeno vem provocando um impacto orçamentário sem precedentes, causando fortes distorções que podem comprometer a equidade na sua prestação. Ademais, muito se tem discutido se o fenômeno da judicialização da política, ao invés de contribuir para o amadurecimento e fortalecimento do Estado Democrático de Direito, implicaria em afronta ao princípio da separação dos poderes, consagrado na Constituição Federal de 1988.

Para o desenvolvimento da problemática, a metodologia a ser aplicada será, predominantemente, a pesquisa bibliográfica, pautada no emprego do dedutivo, uma vez que se pretende analisar a doutrina e a legislação pertinente, que versem sobre o fenômeno da judicialização e seus desdobramentos jurídicos, especificadamente, sobre o direito constitucional à saúde, investigando, também, como a jurisprudência do STF têm resolvido questões conflitivas, diante do exame de casos práticos extraídos do repertório forense atual.

O fito dessa pesquisa consubstancia-se no caráter informativo à população à qual é dirigido o direito fundamental à saúde, resultando assim, na tentativa

as instituições contemporâneas. A aproximação das ideias de constitucionalismo e democracia produziu uma nova forma de organização política, que atende por nomes diversos: Estado democrático de direito, Estado constitucional de direito, Estado constitucional democrático [conceito utilizado nesse trabalho]. Seria mau investimento de tempo e energia especular sobre sutilezas semânticas na matéria. BARROSO, Luís Roberto. Neoconstitucionalismo e Constitucionalização do Direito (o triunfo tardio do Direito Constitucional no Brasil). Revista Eletrônica sobre a Reforma do Estado (RERE), Instituto Brasileiro de Direito Público, nº 9, mar./abr./maio, Salvador/Bahia. 2007, p. 03. Disponível em: <http://www.direitodoestado.com/revista/RERE-9-MAR\%C7O-2007-LUIZ\%20 ROBERTO\%20BARROSO.pdf>. Acesso em: 15 jun. 2015. 
de fomentar a melhoria do acesso aos serviços públicos, aclarando entendimentos quanto à possibilidade de ingresso no Judiciário, cujo ativismo reverbera-se indispensável à promoção da Dignidade Humana.

\section{O POSTULADO DA RESERVA DO POSSÍVEL E A PROTEÇÃO DO MÍNIMO EXISTÊNCIAL NO ÂMBITO DA SAÚDE}

No decorrer da construção da teoria dos direitos fundamentais, sustentou-se, por muito tempo, a tese de que apenas os direitos a prestações positivas envolveriam a noção de custos, a serem financiados pelo Estado. Hodiernamente, tal entendimento restou sepultado após o reconhecimento de que os direitos a prestações negativas também envolvem custos. Assim, parte-se da premissa de que a efetivação de todo e qualquer direito depende, necessariamente, da realização de custos públicos.

Também não se discute o fato de o Estado Democrático de Direito caracterizar-se por oferecer uma vasta proteção aos Direitos Fundamentais, visando a sua plena efetividade. A grande questão a ser dirimida circunda ao redor da ideia de que a concretização desses direitos impõe a realização de gastos públicos, que devem ser suportados pelos recursos públicos, os quais, conforme se sabe, são escassos. Surge, assim, a problemática referente à questão da escassez dos recursos públicos, sobretudo, no que tange à prestação dos direitos sociais, cuja concretização, a priori, dá-se por meio da execução de políticas públicas. ${ }^{4}$

Nesse diapasão, a realização dos direitos sociais, com ênfase ao direito fundamental à saúde, requer a tomada das chamadas escolhas trágicas, "que implica demonstrar a relação entre as escolhas realizadas pela sociedade e suas consequências, sempre com os olhos voltados para os valores de cada sociedade" ${ }^{\prime \prime}$, ponderando-se o contexto histórico.

Outro traço marcante relativo à concretização dos direitos sociais revela o seu caráter progressivo. Isso porque os direitos prestacionais não podem ser disponibilizados integralmente de uma única vez. Outrossim, são direitos oferecidos e garantidos pelo Estado progressivamente e em ritmo crescente, a fim de que se tornem cada vez mais concretizados. Esse conceito, quando aplicado diretamente ao direito fundamental à saúde, implica no reconhecimento de que os objetivos do SUS, traçados pela Constituição (art. 196) e pela legislação infraconstitucional, não poderão ser efetivados de plano, visto que restam condicionados a outros fatores, como ao desenvolvimento científico e tecnológico da medicina, bem como às limitações próprias dos recursos

\footnotetext{
${ }^{4}$ Verifica-se que: "Política pública é o conjunto de medidas e procedimentos estatais, diretas ou indiretas, que buscam atingir uma meta ideal. Neste sentido, o dever do Estado é o de desenvolver mecanismos gerais de atendimento e o direito do indivíduo é ao cumprimento dessas políticas públicas, nos limites em que estabelecidas". CARLINI, Angélica. et al. O CNJ e os Desafios da Efetivação do Direito à Saúde. Belo Horizonte: Fórum, 2011, p. 82.

${ }^{5}$ NUNES, Antônio José Avelãs; SCAFF, Fernando Facury. Os Tribunais e o Direito à Saúde. Porto Alegre: Livraria do Advogado Editora, 2011, p. 99.
} 
públicos disponíveis. Nesse sentido, o entendimento de Queiroz, afirmando que:

(...) a realização desses direitos [sociais] não depende unicamente da institucionalização de uma ordem jurídica nem tão pouco de uma mera decisão política dos órgãos politicamente conformadores, mas da conquista de uma ordem social em que impere uma justa distribuição dos bens, a qual só poderá ser alcançada de modo progressivo (grifo nosso). ${ }^{6}$

Além da constatação de que ao Estado não é possível à realização imediata e definitiva de todos os direitos sociais, necessário se faz lembrar ainda que, enquanto os direitos de primeira dimensão são geralmente garantidos indistintamente a toda sociedade, posto não haver razoabilidade em distinguir quem precisa mais deles, os direitos de segunda dimensão, em razão de sua natureza, podem e devem ser direcionados aos grupos mais fragilizados de uma sociedade, haja vista que almejam a concretização da igualdade material entre os homens, através da máxima de que os desiguais devem ser tratados de forma desigual, na medida de sua desigualdade.

É imprescindível, todavia, se perquirir acerca de a quem se deve atribuir o papel de traçar as denominadas escolhas trágicas, elegendo quais seriam os destinatários e as prioridades dos gastos públicos. No Brasil, conferiu-se ao Poder legislativo o papel de definir, no âmbito de sua atividade discricionária, quais as prioridades públicas que serão realizadas através dos recursos públicos disponíveis. Logo, infere-se que, pelo menos em um primeiro momento, caberá ao Poder Legislativo decidir quais as políticas públicas a serem implementadas e, consequentemente, quais prestações que serão entregues, em consonância com o planejamento orçamentário traçado.

Contudo, essa conformação do legislador não é de toda livre ${ }^{7}$, e deve obediência aos princípios e direitos constitucionalmente assegurados, não podendo ficar aquém do patamar mínimo disposto na Constituição. Nesse sentido, afirmam Sarlet e Figueiredo ${ }^{8}$ que:

\footnotetext{
${ }^{6}$ QUEIROZ, Cristina. O Princípio da Não Reversibilidade dos Direitos Fundamentais Sociais. In: O Princípio da Não Reversibilidade dos Direitos Fundamentais: princípios dogmáticos e prática jurisprudencial. Coimbra: Coimbra Editora, 2006, p. 63.

${ }^{7}$ A temática da formulação de políticas públicas está, em certa medida, ligada à discricionariedade do administrador público, já que "(...) é por meio dela que são sopesados os vários interesses contrapostos. Isso, porém, não se confunde com arbitrariedade, uma vez que do ponto de vista estritamente jurídico, as políticas públicas devem confirmar fins e objetivos anteriormente qualificados pelo ordenamento jurídico como de interesse público, definindo-os como finalidade da atividade administrativa." MEDEIROS, Fabrício Juliano Mendes. O Ativismo Judicial e o Direito à Saúde. Belo Horizonte: Fórum, 2011, p. 18.

${ }^{8}$ SARLET, Ingo Wolfgang; FIGUEIREDO, Mariana Filchtiner. Reserva do Possível, Mínimo Existencial e Direito à Saúde: algumas aproximações. In: Revista da Defensoria Pública, ano 1, $\mathrm{n}^{\circ}$ 1, p. 179-234. Disponível em: <http://www.defensoria.sp.gov.br/dpesp/repositorio/20/documentos/ outros/Revista\%20n\%C2\%BA\%201\%20Volume\%201.pdf>. Acesso em: 15 jun. 2015, p. 208.
} 
(...) quem "governa" - pelo menos num Estado Democrático (e sempre constitucional) de Direito - é a Constituição, de tal sorte que aos poderes constituídos impõe-se o dever de fidelidade às opções do Constituinte, pelo menos no que diz com seus elementos essenciais, que sempre serão limites (entre excesso e insuficiência!) da liberdade de conformação do legislador e da discricionariedade (sempre vinculada) do administrador e dos órgãos jurisdicionais.

Já Ana Paula Barcellos ${ }^{9}$ relembra que caberá à constituição democrática, em primeiro lugar, tomar determinadas decisões políticas fundamentais, assegurando-se um mínimo de direitos aos indivíduos, através de seu poder constituinte originário, que permanece fora do alcance da deliberação política e das maiorias. Ainda assim, diante do reconhecimento de que a efetivação dos direitos sociais depende de prestações positivas do Estado e que a sua realização encontra-se subordinada às condições econômicas do ente político, surge a necessidade de se impor limites fáticos e jurídicos à sua concretização.

O primeiro dos limites traçados refere-se à teoria da reserva do possível, que surge pela primeira vez em decisão do Tribunal Constitucional alemão no julgamento sobre a inconstitucionalidade da limitação de vagas imposta por algumas Universidades, em face do disposto no artigo 12 , \& $1^{\circ}$ da Lei Fundamental Alemã, que garantia a todos os alemães o direito de eleger livremente a sua profissão, o lugar de trabalho e o lugar de formação. $\mathrm{Na}$ ocasião, o referido tribunal decidiu que: "(...) a prestação de direitos sociais fica na dependência da existência de meios e recursos, mormente os financeiros, o que se manifesta por meio dos orçamentos públicos, bem como da possibilidade de dispor desses meios e recursos, aspectos que compõe as dimensões da reserva do possível".

Vê-se que reserva do possível trata de um conceito econômico, que surge do impasse em se adequar a questão das inúmeras necessidades humanas, refletidas, sobretudo, nos direitos fundamentais sociais, à limitação imposta pela escassez dos recursos públicos. Nessa discussão, o que importa filtrar é que a efetivação das garantias constitucionais de segunda dimensão subordina-se e vincula-se à realidade orçamentária do Estado. Busca-se, portanto, "adequar a realização de direitos à realidade fática". ${ }^{10}$

Ao Estado cabe, portanto, se valer de todos os meios possíveis para promover a adequação entre suas possibilidades e as necessidades essenciais dos cidadãos, considerando a razoabilidade da pretensão individual ou social e disponibilidade financeira de efetivar a prestação. Sustenta-se que mesmo

\footnotetext{
${ }^{9}$ BARCELLOS, Ana Paula de. Conclusão: o mínimo existencial como núcleo sindicável da dignidade da pessoa humana. Uma proposta de concretização a partir da Constituição de 1988. In: A Eficácia Jurídica dos Princípios Constitucionais: o princípio da dignidade humana. 3. ed., Rio de Janeiro: Renovar, 2011, p. 249.

${ }^{10}$ SBRISSIA, Larissa Fischer. A Efetividade dos Direitos Fundamentais Sociais frente à Reserva do Possível. Disponível em: <http://www.unibrasil.com.br/arquivos/direito/20092/larissa-fischersbrissia.pdf>. Acesso em: 15 jun. 2015, p. 3.
} 
detendo o Estado os recursos materiais, não se deve pensar em um dever de prestar algo que não se mantenha dentro dos limites do razoável. ${ }^{11}$

Observa-se, todavia, que a aplicação e alegação da reserva do possível têm sido vistas com fortes ressalvas no Brasil, sobretudo, pelo Poder Judiciário quando da análise de ações que buscam a efetivação dos direitos sociais. Assevera-se que, muitas vezes, a reserva do possível tem sido utilizada de forma falaciosa, como argumento impeditivo e contrário à intervenção judicial e desculpa genérica para a omissão estatal, sobretudo, no que tange a efetivação dos direitos sociais.

Desta feita, diante do reconhecimento de que o escopo precípuo do Estado Democrático de Direito é promover a efetivação e garantia dos direitos fundamentais, não parece razoável a adoção da reserva do possível como regra, pois, ainda que não se possa pleitear o impossível na seara dos direitos básicos, em especial dos de cunho social. Vê-se que o Estado brasileiro assumiu um pacto para com a sua efetivação, o que implica no dever de pautar sua atividade com vistas à realização daqueles direitos.

$\mathrm{Na}$ tentativa de promover uma solução para o impasse gerado entre a concretização dos direitos fundamentais e a limitação imposta pela escassez dos recursos públicos, foi criado o conceito de mínimo existencial, como limitação a própria aplicação da reserva do possível.

De fato, partindo-se da premissa de que os direitos sociais guardam estrita correlação com o significado da dignidade humana, a ponto de defender-se que dela retiram seu fundamento, estudar o mínimo existencial significa estabelecer os limites impostos pela Constituição como garantias sociais mínimas aos indivíduos para que tenham realizada a sua própria dignidade.

Nesse sentido, Barcellos aponta que o mínimo da dignidade refere-se à decisão nuclear tomada pelo poder constituinte originário e imposta à maioria, que terá que respeitá-la, afinal, representa o efeito concreto mínimo pretendido pela norma e exigível. A deliberação política apenas poderá ir além do mínimo existencial para desenvolver a concepção da dignidade prevalente em conformidade com o momento histórico de cada povo. Doravante, a autora ressalta que a noção de mínimo existencial compõe-se de quatro elementos: a educação fundamental, a saúde básica, a assistência aos desamparados e 0 acesso à justiça:

$\mathrm{Na}$ linha do que se identificou no exame sistemático da própria Carta de 1988, o mínimo existencial que ora se concebe é composto de quatro

\footnotetext{
${ }^{11}$ Ao revés, se os recursos financeiros do Estado brasileiro não são suficientes, devem ser, em verdade, retirados de outras áreas menos prioritária, tais como o custeamento de verbas extra de gabinetes governamentais ou parlamentares,onde sua aplicação não está tão intimamente ligada aos direitos essenciais para a realização da vida digna do ser humano. DUARTE, Bento Herculano; GABURRI, Fernando. (coords.) A Fazenda Pública à Luz da Atual Jurisprudência dos Tribunais Brasileiros. Curitiba: Juruá, 2011, p. 65.
} 
elementos, três materiais e um instrumental, a saber: a educação fundamental, a saúde básica, a assistência aos desamparados e o acesso á justiça. Repita-se, ainda uma vez, que esses quatro pontos correspondem ao núcleo da dignidade da pessoa humana a que se reconhece eficácia jurídica positiva e, a fortiori, o status de direito subjetivo exigível diante do Poder Judiciário. ${ }^{12}$

De outra parte aduz Barroso ${ }^{13}$ que o mínimo existencial corresponde às condições elementares de educação, saúde e renda, permitindo ao indivíduo de uma sociedade obter acesso aos valores civilizatórios, bem como participar de forma esclarecida do processo político e debate público. Nesse sentido, atribui aos três Poderes constituídos o dever de realizar os direitos fundamentais, na maior extensão possível, tendo como limite mínimo o núcleo essencial desses direitos. ${ }^{14}$

Ressalta-se, ainda, que a garantia efetiva a uma existência digna vai além da garantia de mera sobrevivência física. Abrange, ainda, um conteúdo mínimo sociocultural, capaz de assegurar ao indivíduo um mínimo de inserção na vida de sua sociedade, na busca da consecução do princípio da igualdade, no que diz respeito ao seu conteúdo material. Infere-se, portanto, que a ideia de mínimo existencial não pode ser reduzida a um mínimo vital ou se sobrevivência, bem como que deve guardar relação com o conteúdo da dignidade da pessoa humana, enquanto princípio constitucional fundamental.

Entende-se que os critérios da razoabilidade e da proporcionalidade deverão estar presentes quando da aplicação da reserva do possível como limite fático e jurídico a concretização dos direitos básicos, em especial, dos direitos sociais. Todavia, sua aplicação não poderá denotar proteção insuficiente a tais direitos, sobre pena de caracterizar-se sua inconstitucionalidade. A reserva do possível deve, portanto, obediência ao núcleo essencial dos direitos fundamentais, representado, aqui, em torno da ideia do mínimo existencial.

Tomando como cenário as ações individuais que eclodem no Judiciário, na busca pela concessão de ações e serviços de saúde, muito se tem discutido

\footnotetext{
12 BARCELLOS, Ana Paula de. Conclusão: o mínimo existencial como núcleo sindicável da dignidade da pessoa humana. Uma proposta de concretização a partir da Constituição de 1988. In: A Eficácia Jurídica dos Princípios Constitucionais: o princípio da dignidade humana. 3. ed., Rio de Janeiro: Renovar, 2011, p. 253.

${ }^{13}$ BARROSO, Luís Roberto. Da Falta de Efetividade à Judicialização Excessiva: direito à saúde, fornecimento gratuito de medicamentos e parâmetros para a atuação judicial. In: Revista Jurídica UNIJUS, Minas Gerais, v. 11, no 15, p. 13-38, nov. 2008. Disponível em: <http://www.uniube.br/ publicacoes/unijus/arquivos/unijus_15.pdf>. Acesso em: 15 jun. 2015, p. 19.

${ }_{14}$ Desta feita, o Estado possui não somente o poder-dever de se abster de praticar atos atentatórios a dignidade humana, mas também o de promover esta dignidade por meio de condutas ativas, garantindo o mínimo existencial para cada pessoa humana em seu território. Por certo, o homem tem a sua dignidade aviltada não somente quando se vê privado de alguma das suas liberdades fundamentais, mas também quando não possui acesso à alimentação, educação básica, saúde, moradia, etc. SARMENTO, Daniel. A Ponderação de Interesses na Constituição. Rio de Janeiro: Lúmen Juris, 2000, p. 71.
} 
acerca da adoção de parâmetros para a atuação judicial no sentido de minimizar o impacto orçamentário gerado no âmbito do SUS, que, em última análise, compromete a implantação e a execução de suas políticas públicas.

Outrossim, tem-se proclamado pelo uso da reserva do possível e pelo mínimo existencial como critérios materiais a serem combinados a fim de assegurar a eficácia e efetividade do direito à saúde, reconhecendo como legítima a atuação do Poder judiciário nessa esfera, partindo-se da premissa de que a realização dos direitos fundamentais, em um Estado Constitucional Democrático, não poder ficar à margem dos princípios orçamentários, bem como da separação dos Poderes.

A reserva do possível, enquanto limite fático e jurídico imposto à realização dos direitos fundamentais, mormente à efetivação do direito fundamental à saúde, revela-se sobre duas dimensões. A primeira delas trata da dimensão fática da reserva do possível, atrelada a inexistência ou insuficiência de recursos para efetivar os direitos sociais. Em contrapartida, a dimensão jurídica trata da existência de recursos, que, por algum motivo, não estão disponíveis ou não podem ser utilizados. Assim, ainda que existam recursos, esse fato por si só, não autorizaria, a priori, o titular de um direito social a efetivá-lo. ${ }^{15}$

Com relação à disponibilidade fática dos recursos, é de suma importância a constatação de que esta não se resume ao campo meramente econômico, ao passo que abrange outros recursos materiais e humanos. No âmbito do SUS esse quadro pode ser retratado pela falta de pessoal especializado e de leitos disponíveis em hospitais. Nesse caso, necessário se faz investigar se a demanda não está sendo atendida em face da total indisponibilidade de meios, ou por ineficiência na alocação dos recursos públicos, principalmente daqueles constitucionalmente vinculados, como no caso dos arts. 195 e 198, ambos da Constituição atual, que tratam, respectivamente, do financiamento da Seguridade Social e da Saúde.

Isto posto, compreende-se que a alegação fática da reserva do possível só poderia ser suscitada quando restar comprovado à inexistência ou insuficiência dos recursos, bem como que as verbas disponíveis foram aplicadas em consonância com os ditames constitucionais, sabendo-se que o ônus de comprovar o argumento referente à inexistência de recursos recai sobre a própria Administração Pública, bem como da demonstração de que esses foram devidamente aplicados.

No que se refere à impossibilidade jurídica, infere-se que guarda íntima relação com questões orçamentárias ${ }^{16}$. Todavia, a aplicação da impossibilidade

\footnotetext{
${ }^{15}$ KELBERT, Fabiana Okchstein. Os Direitos Fundamentais, seus Custos e as Dimensões da Reserva do Possível: análise e possibilidades de superação no âmbito da concretização dos direitos sociais. In: Reserva do Possível e a Efetividade dos Direitos Sociais no Direito Brasileiro. Porto Alegre: Livraria do Advogado, 2011, p. 78-83.

${ }^{16}$ Registra-se que a impossibilidade jurídica pode estar vinculada ao orçamento público já aprovado e que não poderia ser mudado por meio de uma determinação judicial, à exceção da
} 
jurídica dos recursos, na seara da saúde, há que ser submetida aos critérios da proporcionalidade e do respeito ao núcleo essencial desse direito, no sentido de não se permitir que a prestação estatal fique aquém de um patamar minimamente eficaz para sua garantia. ${ }^{17}$

Aqui, sustenta-se que surge para o Poder judiciário a possibilidade de exercer controle sobre as opções orçamentárias e dos gastos públicos em geral, permitindo-se redirecionar recursos, ou até mesmo suplementá-los, no âmbito daqueles disponíveis, o que, na prática, implica no deslocamento de recursos destinados a outras áreas, para a concretização dos mandamentos jurisdicionais que concedem tratamentos de saúde dos mais diversos.

Por outro lado, a aplicação da reserva do possível traz, ainda, a noção da proteção contra o esvaziamento de outras prestações, tratada por Kelber como sendo sua dimensão negativa, a qual, consoante a autora, implica em reconhecer que:

(...) partindo-se da ideia central de que efetivamente não há recursos suficientes a satisfazer todos os direitos fundamentais, especialmente os sociais, a dimensão negativa da reserva do possível atuaria como impedimento à satisfação de uma prestação que pudesse comprometer a satisfação de outra prestação. Em outras palavras, esse seria o caso, por exemplo, de concessão de uma prestação excessivamente onerosa que esgotasse os recursos destinados a concretizar outros direitos. ${ }^{18}$

Contudo, ao usar da reserva do possível para se restringir um direito em favor de outro, o que, no campo da saúde pública, importa em negar tratamento individual, em prol da saúde da coletividade, é necessário o atendimento ao critério da proporcionalidade. Extrai-se que "a proporcionalidade é a forma de controle da atividade discricionária de todos os poderes estatais, especialmente do Legislativo e do Executivo".

A proporcionalidade deve atentar para três requisitos, o da adequação, que pressupõe que o meio utilizado pelo legislador e pela Administração Pública seja adequado para promover o resultado pretendido, o da necessidade, impondo que o meio empregado seja o menos gravoso para promover o fim pretendido, e, por fim, o da proporcionalidade em sentido estrito, que exige

\footnotetext{
possibilidade de remanejamento de verbas previsto na própria lei orçamentária ou surge na ausência de lei orçamentária que autorize a realização de gastos. DUARTE, Bento Herculano; GABURRI, Fernando. (Coords.) A Fazenda Pública à Luz da Atual Jurisprudência dos Tribunais Brasileiros. Curitiba: Juruá, 2011, p. 67.

17 SARLET, Ingo Wolfgang; FIGUEIREDO, Mariana Filchtiner. Reserva do Possível, Mínimo Existencial e Direito à Saúde: algumas aproximações. In: Revista da Defensoria Pública, ano 1, $\mathrm{n}^{\circ}$ 1, p. 179-234. Disponível em: <http://www.defensoria.sp.gov.br/dpesp/repositorio/20/documentos/ outros/Revista\%20n\%C2\%BA\%201\%20Volume\%201.pdf>. Acesso em: 15 jun. 2015, p. 207-208.

${ }_{18}$ KELBERT, Fabiana Okchstein. Os Direitos Fundamentais, seus Custos e as Dimensões da Reserva do Possível: análise e possibilidades de superação no âmbito da concretização dos direitos sociais. In: Reserva do Possível e a Efetividade dos Direitos Sociais no Direito Brasileiro. Porto Alegre: Livraria do Advogado, 2011, p. 87-88.
} 
que as vantagens decorrentes da promoção do fim sejam maiores que a restrição de outro direito fundamental.

Outro aspecto relevante a ser analisado, trata da escolha técnica empregada na elaboração dos Protocolos Clínicos e Diretrizes Terapêuticas, os quais serão mais bem detalhados no curso do presente estudo. Referidos Protocolos buscam a uniformização das condutas de tratamento no âmbito do SUS, pautados na garantia da eficiência e segurança dos tratamentos e medicamentos indicados. Com fulcro na reserva do possível, o Estado não dispõe de recursos para disponibilizar a população todos os tipos de drogas existentes no mercado, sobretudo, em face do avanço da indústria farmacêutica e da medicina, devendo, portando, estabelecer escolhas alocativas, representadas pela formalização de listas de medicamentos a serem disponibilizados gratuitamente pelos Poderes Públicos.

Ainda que tais escolhas mereçam e devam servir de parâmetro para a atuação judicial na seara da saúde, é certo que muitos desses Protocolos encontram-se desatualizados, bem como que, diante do caso concreto, possa restar configurado que o medicamento indispensável à vida do requerente não se encontra contemplado pelo SUS. Nesses casos, novamente, exsurgem os princípios da proporcionalidade e da razoabilidade como critérios para aplicação da reserva do possível.

Nesse sentido, apontam Scarlet e Figueiredo ${ }^{19}$ que não se mostra razoável, por exemplo, compelir o Estado ao fornecimento de medicamentos e tratamentos de caráter experimental, ou que não possuam indicação clínica para a patologia daquele que o requer judicialmente, demonstrando, em muitos casos, que o paciente serve de verdadeira cobaia para indústria farmacêutica, a custa de recursos públicos, numa clara violação ao princípio da dignidade humana. Os autores apontam, ainda, que essa situação, se levada ao extremo, pode reclamar no dever de proteção da pessoa contra si mesma, por parte do Estado e de terceiros.

Tem-se como certo que o mínimo existencial, quando relacionado ao direito à saúde, não pode ser encarado como um mínimo de sobrevivência impele-se que esse núcleo essencial deve conferir condições dignas para o gozo de uma vida de qualidade. No Brasil, ainda que não exista previsão constitucional expressa no sentido de se garantir o direito ao mínimo existencial, é certo que sua existência independe de tal previsão, visto, em última análise, vem a enfatizar a própria garantia a uma existência digna.

Trazendo a questão para a seara da saúde, Barcellos ${ }^{20}$ explica que, além

\footnotetext{
${ }^{19}$ SARLET, Ingo Wolfgang; FIGUEIREDO, Mariana Filchtiner. Reserva do Possível, Mínimo Existencial e Direito à Saúde: algumas aproximações. In: Revista da Defensoria Pública, ano 1, $\mathrm{n}^{\circ}$ 1, p. 179-234. Disponível em: <http://www.defensoria.sp.gov.br/dpesp/repositorio/20/documentos/ outros/Revista\%20n\%C2\%BA\%201\% 20Volume\%201.pdf>. Acesso em: 15 jun. 2015, p. 223-225. ${ }^{20}$ BARCELLOS, Ana Paula de. O Direito a Prestações de Saúde: complexidades, mínimo existencial e o valor das abordagens coletiva e abstrata. In: Revista da Defensoria Pública, ano 1,
} 
do conjunto de prestações mínimas traçado pela Constituição, o poder público poderá optar por garantir outras necessidades de saúde. Nesse diapasão, ao Poder judiciário será cabível a determinação para o fornecimento de tratamentos compreendidos no conceito do mínimo existencial, independentemente de existir uma ação específica da Administração ou do Legislativo nesse sentido, mas, não deverá fazê-lo em relação aos serviços que não se enquadram nesse conceito, salvo se já tiverem sido efetivados pelo Poder Público, e ganhado a força de lei.

Ao mínimo existencial relacionado ao direito fundamental à saúde, devem-se aplicar, ainda, as modalidades de eficácia negativa, interpretativa e vedativa do retrocesso.

Explica-se: (i) o Poder Público não pode tomar decisões prejudiciais à saúde da população, que poderão ser anuladas pelo Judiciário (negativa); (ii) dentre várias interpretações de um ato normativo que tenha disposto sobre o assunto, deverá ser escolhida aquela que mais amplamente realiza o propósito de atender à saúde da população em geral e dos indivíduos em particular (interpretativa); e, por fim, (iii) não poderá o Poder Público extinguir uma ação, ou revogar uma norma, que proporcione um determinado benefício ou prestação na área de saúde, reduzindo o status geral já alcançado na matéria, sem uma medida correspondente ou substituta, sob pena de agir inconstitucionalmente (vedativa do retrocesso). ${ }^{21}$

Importa frisar que o conteúdo do mínimo existencial não será o mesmo para cada indivíduo, sendo necessária a promoção de sua contextualização, a fim de se evitar tratamentos não condizentes com os ditames da isonomia material. Assim, o mínimo existencial, quando tratado como parâmetro para exigibilidade do direito fundamental à saúde, deve ser analisado à luz das necessidades de cada indivíduo, bem como do grupo político e social, no qual está inserido.

Surge, então, a problemática ligada à gratuidade dos serviços de saúde prestados no âmbito do SUS. Como visto, o constituinte permitiu que a iniciativa privada participasse da assistência à saúde, e com isso assentou a discussão acerca das desigualdades sociais presentes no país. De fato, aqueles que gozam de recursos materiais suficientes para contratar assistências privadas de saúde (planos de saúde) poderão acessar todos os serviços promovidos no âmbito do SUS sem nenhum tipo de limitação, nas mesmas condições dos

\footnotetext{
no 1, p. 133-178. Disponível em: <http://www.defensoria.sp.gov.br/dpesp/repositorio/20/documentos/ outros/Revista\%20n\%C2\%BA\%201\%20Volume\%201.pdf>. Acesso em: 15 jun. 2015, p. 136.

${ }^{21}$ BARCELLOS, Ana Paula de. Conclusão: o mínimo existencial como núcleo sindicável da dignidade da pessoa humana. Uma proposta de concretização a partir da Constituição de 1988. In: A Eficácia Jurídica dos Princípios Constitucionais: o princípio da dignidade humana. 3. ed., Rio de Janeiro: Renovar, 2011, p. 273.
} 
indivíduos que não estejam aptos a prover com recursos próprios a sua saúde e a de seus familiares. Em se tratando de direitos sociais, sustenta-se que a efetiva necessidade haveria de servir como parâmetro a ser levado a sério, em conjunto com os princípios da solidariedade, da subsidiariedade e da proporcionalidade. $^{22}$

Imperioso destacar a necessidade de buscar-se efetivar o mínimo existencial em face das circunstâncias concretas relacionadas a cada indivíduo, num sentido de que a garantia resguarda o direito de ser tratado como igual, e não propriamente a receber prestações iguais, sustentando que a universalidade dos serviços não implica necessariamente na gratuidade de suas prestações, assim como a integralidade do atendimento não significa que toda e qualquer prestação tenha que ser concretizada em termos ótimos.

Tem-se, ainda, o debate acerca de quais prestações deverão ser ofertadas pelo poder público, não sobre a ótica da reserva do possível e, consequentemente, da impossibilidade fática dos recursos, mas sobre a ótica do mínimo possível a ser aplicado individualmente, o que reclama a dilação probatória como meio para eleição das alternativas e tratamentos que se mostram eficientes em cada caso.

De fato, a mera apresentação de receituário médico não deve ser encarada como prova cabal capaz de promover a condenação do ente público ao tratamento pleiteado. Antes disso, impõe-se a análise acerca de sua efetiva necessidade, bem como da existência de alternativas que envolvam menores custos, promovendo o atendimento de um maior número de indivíduos com o mesmo comprometimento orçamentário.

Vale depurar a grande dificuldade em se estabelecer o conteúdo do mínimo existencial de saúde, visto que este, em muitos casos, não admite gradações: ou se concede o tratamento na expectativa de se obter a cura, ou o indivíduo simplesmente morrerá. Contudo, ressalta que analisar o mínimo existencial relacionando-o simplesmente como o estado de saúde final do indivíduo é errôneo, mesmo porque muitas vezes não há controle sobre o resultado final que um tratamento surtirá no paciente. É preciso analisar as prestações de saúde disponíveis que podem ser satisfatórias quando aplicadas ao caso concreto, e, dentre elas, eleger aquela que, garantindo um mínimo de saúde, atende aos princípios orçamentários.

Nesse caso, vê-se que não se trata de optar por uma lógica utilitarista, fazendo uso da escassez para promover prestações de saúde que atinjam ao maior número de pessoas pelo menor custo. Busca-se, efetivamente, a promoção da garantia ao mínimo existencial de cada indivíduo, através da

22 SARLET, Ingo Wolfgang; FIGUEIREDO, Mariana Filchtiner. Reserva do Possível, Mínimo Existencial e Direito à Saúde: algumas aproximações. In: Revista da Defensoria Pública, ano 1, $n^{\circ}$ 1, p. 179-234. Disponível em: <http://www.defensoria.sp.gov.br/dpesp/repositorio/20/documentos/ outros/Revista\%20n\%C2\%BA\%201\% 20Volume\%201.pdf>. Acesso em: 15 jun. 2015, p. 220. 
alternativa que minimize o impacto orçamentário, em harmonia com os ideais de igualdade e da justiça distributiva. ${ }^{23^{3}}$

Infere-se, portanto, que a intenção do legislador constituinte originário era de que todos pudessem desfrutar dos serviços de saúde necessários para promoção, manutenção e recuperação de sua saúde. Entretanto, em face das limitações materiais, apenas um núcleo básico desses direitos se torna exigível, justamente aquele que guarda relação com a dignidade humana e com o direito à vida, que não podem ser concebidos isoladamente. O mínimo de saúde, mais do que assegurar a existência do indivíduo, deve promovê-la de forma digna. Observa-se, que esse mínimo não se restringe ao mínimo vital, mas sim, a um mínimo social, em consonância com a amplitude conferida pelo constituinte ao direito à saúde.

Em se tratando, portanto, do mínimo existencial na seara da saúde, o Judiciário estará autorizado a decidir sobre a eficácia positiva, decorrente do texto constitucional, independentemente da mediação legislativa, bem como a assegurar as prestações tomadas além do mínimo existencial, desde que já contempladas por opções políticas, na forma de leis.

Pari passu, é possível concluir que a reserva do possível só poderá ser suscitada enquanto matéria de defesa pelo ente estatal, no que envolvam ações judiciais para concessão de tratamentos de saúde, quando restar devidamente comprovada impossibilidade fática de promover ações e serviços dessa natureza, frente à inexistência ou insuficiência de recursos, desde que se demonstre a aplicação correta destes, em consonância com os ditames constitucionais e os princípios da proporcionalidade e da razoabilidade, restando preservado o núcleo essencial desse direito, como forma de garantir uma existência digna.

\section{O ATIVISMO JUDICIAL E A BUSCA DA CELERIDADE À PRESTAÇÃO DOS SERVIÇOS DE SAÚDE PÚBLICA NA SEARA DO FORNECIMENTO DE MEDICAMENTOS}

Com o surgimento do Estado Democrático, percebe-se que as disposições constitucionais passaram a gozar de força normativa e efetividade, inclusive, aquelas que se referem aos direitos e garantias fundamentais, em especial, os direitos de segunda dimensão, com ênfase à saúde. Os direitos fundamentais sociais, nesse contexto, começam a ser encarados como verdadeiros direitos subjetivos públicos a prestações estatais, as quais, quando não realizadas, ou quando efetivadas de forma insuficiente, ficam sujeitas a serem efetivadas pela via judicial. Nesse sentido, afirma Barroso:

\footnotetext{
${ }^{23}$ A lógica desse critério é assegurar que todos tenham direito subjetivo a esse conjunto comum e básico de prestações de saúde como corolário imediato do princípio constitucional da dignidade da pessoa humana, podendo exigi-lo caso ele não seja prestado voluntariamente pelo Poder Público. BARCELLOS, Ana Paula de. Conclusão: o mínimo existencial como núcleo sindicável da dignidade da pessoa humana. Uma proposta de concretização a partir da Constituição de 1988. In: A Eficácia Jurídica dos Princípios Constitucionais: o princípio da dignidade humana. 3. ed., Rio de Janeiro: Renovar, 2011, p. 281.
} 
As normas constitucionais deixaram de ser percebidas como integrantes de um documento estritamente político, mera convocação à atuação do Legislativo e do Executivo, e passaram a desfrutar de aplicabilidade direta e imediata por juízes e tribunais. Nesse ambiente, os direitos constitucionais em geral, e os direitos sociais em particular, converteram-se em direitos subjetivos em sentido pleno, comportando tutela judicial específica. ${ }^{24}$

Essa ingerência judicial na esfera política foi denominada de Judicialização da Política ou Politização do Poder Judiciário, e reflete um fenômeno observado na maioria das democracias contemporâneas, sobretudo, naquelas em que, seguindo a experiência norte americana, este Poder desempenha o controle da constitucionalidade das leis. "Em termos genéricos, podemos considerar a judicialização como o fenômeno constituído pela influência do Poder Judiciário nas instituições políticas e sociais." 25

No Brasil, esse fenômeno tem ganhado destaque em razão do crescimento vertiginoso do número de ações judiciais que pretendem a condenação dos entes públicos a prestarem, individualmente, alguma espécie de tratamento de saúde. Nesse sentido, a interferência do Poder judiciário vem extrapolando o controle dos atos administrativos e legislativos, no que tange a sua legalidade e constitucionalidade, para se efetivarem em verdadeiras escolhas alocativas, impactando nas políticas públicas em curso.

É certo que esse ativismo ${ }^{26}$ do Poder Judiciário no campo da saúde abarca as várias alternativas legais atinentes a esse direito. Todavia, é no campo da Assistência Farmacêutica que se tem verificado o maior impacto orçamentário recorrente do processo da judicialização da saúde, ante a grande concentração de ações que requerem o fornecimento de medicamentos. ${ }^{27}$

\footnotetext{
${ }^{24}$ BARROSO, Luís Roberto. Da Falta de Efetividade à Judicialização Excessiva: direito à saúde, fornecimento gratuito de medicamentos e parâmetros para a atuação judicial. In: Revista Jurídica UNIJUS, Minas Gerais, v. 11, no 15, p. 13-38, nov. 2008. Disponível em: <http://www.uniube.br/ publicacoes/unijus/arquivos/unijus_15.pdf $>$. Acesso em: 15 jun. 2015, p. 14.

${ }_{25}$ BORGES, Danielle da Costa Leite; UGÁ, Maria Alicia Dominguez. As Ações Individuais para o Fornecimento de Medicamentos no Âmbito do SUS: características dos conflitos e limites para a atuação judicial. In: Revista de Direito Sanitário, São Paulo, v. 10, nº 1, p. 13-38, mar./jul. 2009. Disponível em: <http://www.revistasusp.sibi.usp.br/pdf/rdisan/v10n1/02.pdf>. Acesso em: 15 jun. 2015, p. 15.

${ }^{26}$ Verifica-se que o ativismo judicial corresponde à atuação do agente público responsável pelos atos decisórios de maneira proativa. O órgão do Poder Judiciário, ao determinar a implementação de políticas públicas, que acarretarão mudanças estruturais, com o intuito de efetivar os direitos sociais, difusos e coletivos, atua como agente político fomentador da concretização dos direitos humanos. Para Luiz Guilherme Marinoni: "É claro que esse amplo poder de execução, conferido ao juiz, tem o objetivo de lhe dar maior flexibilidade para a concessão da providência e do meio executivo que seja, a um só tempo, realmente capaz de dar tutela ao direito e implique a menor restrição possível à esfera jurídica do réu." MARINONI, Luiz Guilherme. Processo de Conhecimento. 10 ed., São Paulo: Revista dos Tribunais, 2012, p. 224-225.

${ }^{27}$ CHIEFFI, Ana Luiza; BARATA, Rita Barradas. Judicialização da Política Pública de Assistência Farmacêutica e Equidade (sic). In: Caderno de Saúde Pública, Rio de Janeiro, v. 25, $\mathrm{n}^{\circ} 8$, p. 1839-1849, ago. 2009. Disponível em: <http://www.scielo.br/pdf/csp/v25n8/20.pdf>. Acesso em: 15 jun. 2015, p. 1840.
} 
Um dos aspectos da assistência médica que mais tem sido alvo das ações judiciais é a assistência farmacêutica, ou seja, a garantia do acesso a medicamentos não disponíveis nos serviços públicos, em razão de preços abusivos praticados pelos fabricantes ou de falta de estoque, padronização do uso, registro no país e comprovação científica de eficácia.

Como visto, o legislador constituinte assegurou acesso universal e igualitário às ações e serviços para a promoção, proteção e recuperação da saúde. No plano infraconstitucional, a Lei $\mathrm{n}^{\circ} 8.080 / 90^{28}$, ao dispor sobre a organização das ações que integram o Sistema único de Saúde, tratou de incluir expressamente a execução de ações de assistência terapêutica integral, inclusive farmacêutica, bem como a formulação da política de medicamentos.

Doravante, os usuários do Sistema Único de Saúde têm recorrido corriqueiramente ao Poder Judiciário para ver efetivada a prestação de serviços de saúde relacionados ao fornecimento de medicamentos. Ocorre que, como bem salienta Barroso, "o sistema, no entanto, começa a apresentar sintomas graves de que pode morrer da cura, vítima do excesso de ambição, da falta de critérios e de voluntarismos diversos". ${ }^{29}$

De fato, a ingerência judicial quanto à concretização do direito fundamental à saúde tem promovido sérias distorções no sistema, refletidas na concessão de medidas jurisdicionais que determinam a concessão de tratamentos destituídos de razoabilidade e essencialidade, representando não apenas um impacto orçamentário sem precedentes, como também ameaçando a concretização dos princípios basilares do SUS, como a prestação de uma cobertura universal, integral e equânime de suas ações e serviços, ao passo que desorganizam a atividade administrativa, impedindo, muitas vezes que a alocação de recursos públicos e a realização das políticas públicas sejam devidamente implementadas.

Isso reflete a incapacidade técnica do Judiciário para resolver conflitos dessa natureza, tanto no sentido de que não dispõe de conhecimentos científicos para decidir sobre o fornecimento de medicamentos, ficando, na maioria das vezes, refém da prescrição médica apresentada pela parte interessada, bem como porque, historicamente, tratou de litígios alusivos à justiça comutativa, e não distributiva, como no caso da realização dos direitos sociais. Nesse sentido, fala-se que o judiciário está habituado a promover

\footnotetext{
${ }^{28}$ BRASIL. Lei no 8.080 , de 19 de setembro de 1990. Dispõe sobre as condições para a promoção, proteção e recuperação da saúde, a organização e o funcionamento dos serviços correspondentes e dá outras providências. Art. 60: "Estão incluídas ainda no campo de atuação do Sistema Único de Saúde (SUS): I - A execução de ações: (...) d) de assistência terapêutica integral, inclusive, farmacêutica; (...) VI - a formulação da política de medicamentos, equipamentos, imunobiológicos e outros insumos de interesse para a saúde e a participação na sua produção; (...)." Disponível em: <http://www.planalto.gov.br/ccivil_03/leis//8080.htm>. Acesso em: 15 jun. 2015.

${ }^{29}$ BARROSO, Luís Roberto. Da Falta de Efetividade à Judicialização Excessiva: direito à saúde, fornecimento gratuito de medicamentos e parâmetros para a atuação judicial. In: Revista Jurídica UNIJUS, Minas Gerais, v. 11, no 15, p. 13-38, nov. 2008. Disponível em: <http://www.uniube.br/ publicacoes/unijus/arquivos/unijus_15.pdf>. Acesso em: 15 jun. 2015, p. 15.
} 
a microjustiça, ao passo que o legislativo e o executivo, por se tratarem de Poderes eleitos pelo voto popular, expressam a vontade democrática da maioria, promovendo a macrojustiça.

Não se pode olvidar, contudo, que promover o respeito e aos direitos fundamentais expressa uma das características marcantes do Estado Constitucional Democrático. E, nesse sentido, correr-se-ia o risco de negarIhes a devida efetividade se restassem limitados à atuação política. Ainda que, a ideia inicial seja de que esses direitos se realizam pela execução de políticas públicas e, consequentemente, pela atuação dos poderes legislativo e executivo, seria impossível não se atribuir ao Judiciário o papel de garantidor do mínimo existencial de cada indivíduo, numa ordem jurídica em que o primado da dignidade humana foi elevado ao status de norma motriz da própria Constituição Federal.

\section{AS TUTELAS INDIVIDUAIS DE URGÊNCIA NA CONCESSÃO DE MEDICAMENTOS POR VIA JUDICIAL: O EMBATE ENTRE O DIREITO À VIDA E A SALVAGUARDA DA SAÚDE COLETIVA}

Atualmente, uma das fortes críticas traçadas à judicialização da saúde atenta para a quebra da equidade dos serviços ofertados pelo SUS, sobretudo, quanto ao fornecimento de medicamentos. Em primeiro lugar, sustenta-se que eleger a via judicial como meio de concessão de tratamentos de saúde privilegia aqueles que têm conhecimentos de seus direitos e condições financeiras para arcar com as custas processuais e honorários advocatícios.

Há ponderações sobre os efeitos negativos do fenômeno da judicialização da saúde sob três principais ângulos. O primeiro aponta que o deferimento absoluto de pedidos judiciais pode aprofundar as iniquidades de acesso no sistema público de saúde, infringindo princípio do SUS, uma vez que favorece aqueles que têm maior possibilidade de veicular sua demanda judicialmente, em detrimento dos que não possuem acesso à justiça; igualmente apontam para o possível comprometimento do princípio da integralidade, uma vez que ações de cunho individual não são estendidas aos demais portadores da mesma condição patológica que poderiam se beneficiar do objeto da demanda. ${ }^{30}$

Ainda que o acesso a medicamentos esteja garantido no âmbito da Assistência Farmacêutica, em diversos níveis de complexidade, muitas das ações de saúde ajuizadas pleiteiam o acesso a medicamentos não padronizados nos protocolos e programas do SUS, e o acolhimento dessas pretensões, representa o estabelecimento de tratamento privilegiado aos indivíduos com poder aquisitivo para contratar um advogado e acionar o Estado. Como resultado, tem-se garantido a poucos indivíduos determinados serviços

\footnotetext{
${ }^{30}$ PEPE, Vera Lúcia Edais, et al. A Judicialização da Saúde e os Novos Desafios da Gestão da Assistência Farmacêutica. In: Ciência e Saúde Coletiva, v. 15, nº 5, p. 2405-2414, ago. 2010. Disponível em: <http://www.scielo.br/scielo.php?script=sci_arttext\&pid=S1413-81232010000500015>. Acesso em: 15 jun. 2015.
} 
(de alto custo) que não são oferecidos pelo SUS, beneficiando a uma minoria, a qual, em princípio, poderia, muitas vezes, arcar com os custos de seu tratamento. $^{31}$

Em segundo plano, contudo, torna-se inegável o ganho em termos de acesso à justiça advinda da organização e implantação da Defensoria Pública, a partir da CF/88. Entretanto, mesmo que se caracterize uma maior proximidade entre as classes menos favorecidas e o judiciário, é necessário reconhecer que nem todos os usuários do SUS buscam tal via para concretização de seus direitos, até mesmo pela falta de conhecimento, que ainda é latente.

Nesse sentido, fala-se que o casuísmo da jurisprudência brasileira pode impedir a devida implementação de políticas públicas dirigidas à promoção da saúde pública. Pois, em muitos casos, o que se testemunha é a concessão de privilégios a alguns jurisdicionados em detrimento da coletividade, que, no mais, continua a depender das políticas universalistas implantadas pelo Poder executivo.

O impacto orçamentário causado pela concessão judicial de tutelas individuais pode, portanto, influir negativamente no amparo do direito à saúde da coletividade, promovendo, em último caso, a sua aniquilação. Essa problemática se mostra ainda mais premente quando analisada sob a ótica das decisões judiciais que determinam a concessão de tratamentos experimentais de custo elevado, que refletem muitas vezes na obrigatoriedade da aquisição de medicamentos que não possuem registro junto à ANVISA e destituídos de estudos clínicos que lhes comprovem à eficácia. ${ }^{32}$

Ademais, os juízes e tribunais não estão habituados a lidar com situações que merecem ser analisadas à luz da justiça distributiva. De fato, ao magistrado, é muito penoso negar um provimento jurisdicional tomando por base o caso concreto de um paciente que corre risco de vida. E, sob esse aspecto, aponta-se que a grande questão a ser dirimida nesses casos não envolve um conflito entre o direito à saúde e à vida de um indivíduo, de um lado, e, de outro, a questão da separação dos poderes e o orçamento. Na realidade,

\footnotetext{
${ }^{31}$ CHIEFFI, Ana Luiza; BARATA, Rita Barradas. Judicialização da Política Pública de Assistência Farmacêutica e Equidade (sic). In: Caderno de Saúde Pública, Rio de Janeiro, v. 25, $\mathrm{n}^{\circ}$ 8, p. 1839-1849, ago. 2009. Disponível em: <http://www.scielo.br/pdf/csp/v25n8/20.pdf>. Acesso em: 15 jun. 2015, p. 1840.

${ }^{32} \mathrm{Em}$ pesquisa realizada no âmbito da Secretaria de Saúde de São Paulo, constatou-se que, no ano de 2006, o cumprimento das decisões judiciais oriundas da comarca da capital representou um gasto orçamentário de 65 milhões de reais, para atender cerca de 3.600 pessoas, ao passo que, em comparação ao mesmo ano, o Estado despendeu 838 milhões de reais para atender 380 mil pessoas cadastradas no Componente Especializado de Assistência Farmacêutica, o que representou, no primeiro caso, o gasto de aproximadamente 18 mil reais por paciente de justiça naquele ano, ao passo que se investiu 2,2 mil reais por pacientes que recebiam administrativamente seus medicamentos. CHIEFFI, Ana Luiza; BARATA, Rita Barradas. Judicialização da Política Pública de Assistência Farmacêutica e Equidade (sic). In: Caderno de Saúde Pública, Rio de Janeiro, v. 25, no 8, p. 1839-1849, ago. 2009. Disponível em: <http://www.scielo.br/pdf/csp/ v25n8/20.pdf>. Acesso em: 15 jun. 2015, p. 1839.
} 
a complexidade desta ponderação envolve o direito à saúde e à vida de uns versus o direito à saúde da coletividade, não havendo solução juridicamente fácil para essa situação, máxime por ter a Constituição assegurando um núcleo essencial desses direitos que se torna inviolável e intangível.

É óbvio que, ao Judiciário, em face de sua inafastabilidade, não será possível negar provimento individual nas situações em que demonstrada violação ao mínimo existencial, seja por ação ou omissão do legislativo e da Administração Pública. O que se pretende é a adoção de critérios mais rigorosos, ante a grande discussão técnica, orçamentária e moral que o fenômeno da judicialização da saúde promove.

Muito se tem primado pela adoção de ações coletivas no âmbito da saúde, como forma de melhor uniformizar a atuação jurisdicional, promovendo a ampliação dos efeitos de suas decisões, na tentativa de promover a equidade no Sistema Único de Saúde. Nesse contexto, merece destaque o ajuizamento da chamada Ação Civil Pública, com fulcro na Lei $n^{\circ} 7.347$, de 24 de Julho de 1985, como instrumento judicial adequado à salvaguarda dos interesses difusos, coletivos e individuais homogêneos, ${ }^{33}$ dentre os quais se compreende o direito fundamental a saúde, consoante dispõe a jurisprudência pátria. ${ }^{34}$

No que pese o reconhecimento da legitimidade do parquet para propositura da Ação Civil Pública já está pacificada, está em trâmite, no Supremo Tribunal

${ }^{33}$ O Código de Defesa do Consumidor (Lei $n^{\circ}$ 8.078/90) definiu os direitos difusos como "os transindividuais, de natureza indivisível, de que sejam titulares pessoas indeterminadas e ligadas por circunstâncias de fato", e os interesses ou direitos coletivos como "os transindividuais de natureza indivisível de que seja titular grupo, categoria ou classe de pessoas ligadas entre si ou com a parte contrária por uma relação jurídica de base". Além desses interesses, o CDCON também conceituou uma terceira categoria de direitos - os interesses ou direitos individuais homogêneos - definidos na lei como aqueles que decorrem de origem comum. Esses direitos são marcadamente individuais, e o aspecto de grupo a eles relativo diz respeito apenas a uma associação de interesses com vistas a um mesmo fim. Não têm, portanto, o caráter transindividual dos interesses coletivos e difusos, nos quais o relevante é o agrupamento em si, e não os indivíduos que o compõem. FILHO, José dos Santos Carvalho. Manual de Direito Administrativo. 22. ed., Rio de Janeiro: Lúmen Juris, 2009, p. 1007.

${ }^{34}$ PROCESSUAL CIVIL. RECURSO ESPECIAL. AÇÃO CIVIL PÚBLICA. FORNECIMENTO DE MEDICAMENTO A MENOR. SAÚDE. DIREITO INDIVIDUAL INDISPONÍVEL. ART. 227 DA CF/88. LEGITIMATIO AD CAUSAM DO PARQUET. ART. 127 DA CF/88. ARTS. 70, 200, e 201 DO DA LEI No 8.069/90. 1. Recurso especial interposto contra acórdão que decidiu pela ilegitimidade ativa do Ministério Público para pleitear, via ação civil pública, em favor de menor, o fornecimento de medicamento. 2. Deveras, o Ministério Público está legitimado a defender os interesses transindividuais, quais sejam os difusos, os coletivos e os individuais homogêneos (grifo do autor). (...) 7. O direito à saúde, insculpido na Constituição Federal e no Estatuto da Criança e do Adolescente, é direito indisponível, em função do bem comum, maior a proteger, derivado da própria força impositiva dos preceitos de ordem pública que regulam a matéria (grifo do autor). Precedentes: REsp no 706.652/SP, Segunda Turma, Rel. Min. Eliana Calmon, DJ de 18.04.2005; REsp no 664.139/RS, Segunda Turma, Rel. Min. Castro Meira, DJ de 20.06.2005; e REsp no 240.033/CE, Primeira Turma, Rel. Min. José Delgado, DJ de 18.09.2000. 10. Recurso especial provido. BRASIL. Supremo Tribunal de Justiça. Recurso Especial $\mathrm{n}^{\circ} 716.512$. $1^{\mathrm{a}}$ Turma. Ministro Relator: Luiz Fux. Publicado no Diário de Justiça em 14 de maio de 2005. Disponível em: <http://www.mp.rs.gov.br/infancia/jurisp/idt267.htm>. Acesso em: 15 jun. 2015. 
Federal, Ação Direta de Inconstitucionalidade $n^{\circ} 3.943$, proposta pela Associação Nacional dos Membros do Ministério Público (Conamp), com o propósito de obter a declaração de inconstitucionalidade do inciso II do artigo $5^{\circ}$ da Lei $7.347 / 85$, que, com a redação que lhe foi dada pela Lei $n^{\circ} 11.448 / 2007$, atribui legitimidade também a Defensoria Pública para propor Ação Civil Pública em defesa dos direitos difusos e coletivos.

A Conamp alega que a disposição legal representa afronta as funções institucionais do Ministério Público, bem como que contraria as funções atribuídas constitucionalmente à Defensoria Pública, no sentido de promover assistência jurídica integral e gratuita aos que não possuem recursos suficientes. Nesse sentido, aponta que as pessoas assistidas pela Defensoria Pública devem ser individualizáveis, o que não é possível em sede de defesa dos direitos difusos, coletivos ou individuais por meio de Ação Civil Pública.

A Associação Nacional dos Defensores Públicos - ANDEP, e a Associação Nacional dos Defensores Públicos da União - ADPU foram admitidas no feito na qualidade de Amicus Curiae, e, em conjunto com a Presidência da República, e com parecer emitido pelo Advogado-Geral da União sustentam que a legitimidade da Defensoria Pública reforça os instrumentos de tutela coletiva, independentemente da aferição dos interessados em sua atuação, o que atenderia aos interesses da sociedade.

Sem dúvida, esse entendimento parece se coadunar mais com a proteção aos direitos difusos e coletivos e individuais homogêneos, de modo a conferir, consoante ressaltado, maior efetividade às disposições constitucionais. Defende-se, aqui, que a Ação Civil Pública a ser promovida tanto pelo Ministério Público quanto pela Defensoria Pública pode representar instrumento jurídico processual hábil a defesa do direito fundamental à saúde, na medida em que possibilita sua consagração coletiva.

Importa frisar que a proteção a esse direito, no âmbito das ações coletivas, não restringe sua possibilidade ao campo da Ação Civil Pública, podendo ainda ser suscitada no âmbito de Mandado de Segurança Coletivo (desde que a matéria não requeira dilação probatória), e até mesmo em sede de ações abstratas de controle de constitucionalidade, nas quais se discuta a validade da locação dos recursos orçamentários para saúde.

Todavia, pelas características inerentes às ações coletivas, sobretudo, no que confere a expansão erga omnes de seus efeitos, é certo que, se devidamente utilizadas enquanto instrumento processual promoverão uma maior igualdade e universalidade no atendimento aos usuários do SUS, ao passo que servirão de instrumento de pressão para constante atualização da Política Nacional de Assistência Farmacêutica, impulsionando a revisão periódica de suas listas e protocolos. Ademais, do ponto de vista da defesa do Estado, essas ações possibilitam a racionalização dos recursos humanos e físicos no âmbito das advocacias e procuradorias públicas. 


\section{A JURISPRUDÊNCIA DO STF EM FACE AO DEVER DE APLICAÇÃO IMEDIATA DO DIREITO À SAÚDE NO BRASIL E OS LIMITES À CONCESSÃO DAS TUTELAS INDIVIDUAIS DE URGÊNGIA QUANTO A MEDICAMENTOS}

No Brasil, em que pese algumas teses contrárias, não há como se adotar entendimento diverso ao positivado na própria Constituição Federal de 1988, que tratou dos direitos fundamentais em Título próprio dos direitos e garantias fundamentais. Em última análise, os direitos sociais guardam estrita correlação com a dignidade da pessoa humana e com o direito à vida, daí sua essencialidade. Entendimento contrário resultaria em lesão ao cidadão, principalmente quando se propõe a redução dos direitos sociais a meras normas de caráter programático, promovendo a anulação de sua força vinculante.

Em verdade, tal concepção se funda no argumento da indeterminação, uma vez que as disposições programáticas prescrevem os fins que devem ser perseguidos pelo Estado, sem que a Constituição Ihe atribua os meios ou o grau de efetividade em que devem ser postas em prática. ${ }^{35}$ Tem-se que:

A dependência de recursos econômicos para a efetivação dos direitos de caráter social leva parte da doutrina a defender que as normas que consagram tais direitos assumem a feição de normas programáticas, dependentes, portanto, da formulação de políticas públicas para se tornarem exigíveis. Nesse sentido, também se defende que a intervenção do Poder Judiciário, ante a omissão estatal quanto á construção satisfatória dessas políticas, violaria o princípio da separação dos Poderes e o princípio da reserva do financeiramente possível. ${ }^{36}$

Destarte, os direitos sociais assumem a característica de normas programáticas, que devem ser encarados sobre a particularidade da progressividade. Seria impossível ao legislador constituinte originário traçar todo o seu conteúdo material, tendo em vista, inclusive, o fato de que estes se adéquam conforme a conjuntura histórica. Assim, a Constituição de 1988 elege um núcleo básico dos direitos sociais, que, por gozarem da prerrogativa da fundamentalidade, encontram-se sujeitos a lógica do artigo $5^{\circ}, \S 1^{\circ}$, que dispõe: "As normas definidoras dos direitos e garantias fundamentais têm aplicação imediata". Nesse sentido, gozam da máxima efetividade possível.

Esse entendimento implica em algumas consequências, que se refletem no reconhecimento da inviolabilidade e da intangibilidade dos direitos sociais; considera-se constitucionalmente garantido o núcleo essencial desses direitos, como também as prestações efetivadas pelo Poder Público na forma de leis,

\footnotetext{
${ }^{35}$ MEDEIROS, Fabrício Juliano Mendes. O Ativismo Judicial e o Direito à Saúde. Belo Horizonte: Fórum, 2011, p. 61-62.

${ }^{36}$ BRASIL. Supremo Tribunal Federal. Agravo Regimental na Suspensão de Tutela Antecipada $n^{\circ}$ 175-CE. Agravante: União. Agravados: Ministério Público Federal, Município de Fortaleza e Clarice Abreu de Castro Neves. Relator: Ministro Gilmar Mendes. Brasília, 17 de março de 2010. Publicado no Diário de Justiça Eletrônico em 30 de abril de 2010. Disponível em: <http://redir.stf. jus.br/paginadorpub/paginador.jsp?docTP=AC\&docID=610255>. Acesso em: 15 jun. 2015.
} 
em clara alusão à proibição da vedação do retrocesso, de modo que os direitos sociais não poderão ser revogados, sem uma justificativa e alternativa compensatórias.

Nessa esteira, vêm-se ofertando ao direito fundamental à saúde, enquanto direito social, o atributo de verdadeiro direito subjetivo público a prestações positivas do Estado, que pode ser tutelado individualmente e exigível em juízo, quando caracterizada a omissão dos Poderes legislativo e executivo, bem como quando restar consignado a sua proteção insuficiente. Reconhece-se, portanto, que o direito à saúde apresenta-se tanto em sua dimensão coletiva, quanto individualmente. A dimensão individual do direito à saúde fora bem ressaltada pelo Ministro Celso de Mello ${ }^{37}$.

Todavia, não se pode olvidar que, por se tratar de direito que envolve prestações positivas do Estado, a sua realização liga-se, frequentemente, a problemática da alocação dos recursos públicos, diante da constatação de sua escassez. Assim, sustenta-se a tese de que a concretização do direito à saúde restaria condicionada à disponibilidade fática dos recursos, envolvendo a efetiva disponibilidade ou não do objeto (bens materiais ou recursos humanos), bem como à disponibilidade jurídica de disposição, já que o Estado, mais do que possuir recursos, precisa estar autorizado a dispor deles.

A temática do postulado da reserva do possível foi debatida, com destaque, durante o julgamento da Arguição de Preceito Fundamental $n^{\circ} 45$, impetrada pelo Partido da Social Democracia Brasileira (PSDB) contra veto do Presidente da República a dispositivo contido na proposição legislativa que veio a se converter na Lei de Diretrizes Orçamentárias no 10.707/2003, sob a alegação de que o veto presidencial importaria em desrespeito a preceito fundamental que garantia a aplicação mínima dos recursos a serem empregados pelos entes federativos no financiamento do SUS. Em que pese ter resultado prejudicada, o Ministro Celso de Mello enfrentou a matéria e justificou a análise com base na dimensão política da jurisdição constitucional, de modo que o STF não poderia esquivar-se de garantir a efetividade dos direitos sociais. ${ }^{38}$

No que tange a aplicação do postulado da reserva do possível no âmbito da saúde pública, o STF já decidiu: "As divergências doutrinárias quanto ao efetivo âmbito de proteção da norma constitucional do direito à saúde decorrem,

\footnotetext{
${ }^{37}$ BRASIL. Supremo Tribunal Federal. Agravo Regimental no Recurso Extraordinário no 271.286-RS. Agravante: Município de Porto Alegre. Agravada: Diná Rosa Vieira. Relator: Ministro Celso de Mello. Brasília, 12 de setembro de 2000. Publicado no Diário de Justiça Eletrônico em 24 de novembro de 2000. Disponível em: <http://redir.stf.jus.br/paginadorpub/paginador.jsp?docTP=AC\&docID=335538> . Acesso em: 15 jun. 2015.

${ }^{38}$ BRASIL. Supremo Tribunal Federal. Arguição de Descumprimento de Preceito Fundamental no 45 . ARGDO: Presidente da República. ARGTE: Partido da Social Democracia Brasileira. Relator: Ministro Celso de Mello. Publicada em 04 de janeiro de 2004. Disponível em: <http://www.stf. jus.br/ portal/jurisprudencia/listarJurisprudencia.asp?s1=\%28ADPF\%24\%2ESCLA\%2E+E+45\%2ENUME\% 2E\%29\&base=basePresidencia>. Acesso em: 15 jun. 2015.
} 
especialmente, da natureza prestacional desse direito e da necessidade de compatibilização do que se convencionou denominar de "mínimo existencial" e da "reserva do possível". ${ }^{39}$

Em suma, ao analisar a teoria da reserva do possível sob o prisma da efetivação dos direitos sociais, a Suprema Corte tem decidido que, tais direitos, principalmente por requererem uma atuação positiva do Estado, envolvem de forma direta a noção de custos. Razão pela qual, muitas vezes, não será possível promover sua efetivação imediata, assim como o Estado não estará obrigado a cumprir com prestações que, no caso concreto, não se mostrem razoáveis. No entanto, a questão da limitação imposta pela reserva do possível não pode ser invocada pela Administração como forma de fugir ao seu dever constitucional de realizar os direitos sociais, promovendo, a contrário senso, o seu aniquilamento.

Ao tratar das teses controversas, que circundam a natureza do direito fundamental à saúde, o Ministro Gilmar Mendes explicou que buscam definir se e em que medida esse direito traduz-se em direito público subjetivo a prestações do Estado, que podem vir a ser garantidas pela via judicial. Apontou que as divergências doutrinárias decorrem fundamentalmente da natureza prestacional do direito à saúde e sua compatibilização com os postulados da reserva do possível e do mínimo existencial.

Nesse contexto, preconiza-se que a dependência de recursos econômicos para efetivação dos direitos sociais corrobora a tese segundo a qual as normas consagradoras desses direitos possuem natureza programática, sendo dependentes da formulação de políticas públicas para tornarem-se exigíveis. Ademais, seria preciso levar em consideração que a prestação devida pelo Estado a cada indivíduo varia conforme sua necessidade, conforme os critérios definidos pela justiça distributiva, que implica na formulação de políticas públicas baseadas em escolhas alocativas ("trágicas"), com vistas a promover a macrojustiça. Defende-se, em face desses argumentos, que a intervenção do Poder judiciário violaria o princípio da separação dos poderes e da reserva do possível.

Por outro lado, o Ministro aponta que os defensores da atuação do Poder Judiciário na concretização dos direitos sociais, em especial do direito fundamental à saúde, ressaltam que tal intervenção é indispensável à realização da dignidade da pessoa humana, de modo que ao menos o núcleo essencial desse direito, denominado de mínimo existencial, não poderia deixar de ser objeto de apreciação judicial.

\footnotetext{
${ }^{39}$ BRASIL. Supremo Tribunal Federal. Agravo Regimental na Suspensão de Tutela Antecipada no 175-CE. Agravante: União. Agravados: Ministério Público Federal, Município de Fortaleza e Clarice Abreu de Castro Neves. Relator: Ministro Gilmar Mendes. Brasília, 17 de março de 2010. Publicado no Diário de Justiça Eletrônico em 30 de abril de 2010. Disponível em: <http://redir. stf.jus.br/paginadorpub/paginador.jsp?docTP=AC\&docID=610255>. Acesso em: 15 jun. 2015.
} 
Diante do valor atribuído aos argumentos traçados, assevera-se a necessidade da realização de juízos de ponderação diante das especificidades de cada caso concreto. Nesse sentido, verifica-se que é possível estabelecer limites e possibilidades à implementação do direito fundamental à saúde, a partir de seis elementos extraídos da própria Constituição Federal de 1988, a saber: 1) a saúde, enquanto direito de todos; 2) a saúde, enquanto dever do Estado; 3) a saúde garantida por políticas sociais e econômicas; 4) a saúde garantida por políticas sociais e econômicas que visem à redução do risco de doenças e de outros agravos; 5) a saúde regida pelo princípio do acesso universal e igualitário; e, por último, 6) a organização das ações e serviços para promoção, proteção e recuperação da saúde.

Constatada, nesse diapasão, a necessidade de se redimensionar a questão da judicialização do direito fundamental à saúde no Brasil deve-se tratar de algumas questões que atuam como paradigmas no trato, pelo Judiciário, de decisões que se referem a esse direito, devendo ser seguidas também no que tange ao fornecimento de medicamentos.

Ao tratar dos pedidos judiciais que requerem a concessão de algum tratamento já contido em políticas públicas, o entendimento é que, ao deferi-lo, o Judiciário não está criando política pública, mas apenas determinando o seu cumprimento, evidenciando-se, nesse caso específico, a existência de um direito público subjetivo à política pública tratada. Já os casos que envolvem prestações não contidos em políticas públicas, há que se analisar se a não prestação decorre de (1) omissão legislativa ou administrativa, (2) de uma decisão administrativa de não fornecê-las, (3) de uma vedação legal a sua dispensação.

Nesse desiderato, aponta-se que, não raro, busca-se, no Poder Judiciário, a condenação do Estado ao fornecimento de medicamento não registrado na Agência Nacional de Vigilância Sanitária (ANVISA). Nesses casos, entende-se haver uma vedação legal a sua concessão, em razão do disposto na Lei $n^{\circ}$ 6.360 , de 23 de setembro de 1976, que, em seu artigo 12 determina que: "nenhum dos produtos de que trata esta Lei, inclusive os importados, poderá ser industrializado, exposto à venda ou entregue ao consumo antes de registrado no Ministério da Saúde". ${ }^{40}$

Ressalta-se que o registro do medicamento junto à ANVISA cumpre com o papel de garantir a saúde pública, atestando a segurança e eficácia do produto, ao mesmo tempo em que realiza a regulação econômica dos fármacos. Isso porque, em se tratando de droga nova que se assemelha a medicamento já existente no mercado e que possui a mesma indicação clínica,

\footnotetext{
${ }^{40}$ BRASIL. Lei $n^{\circ} 6.360$, de 23 de setembro de 1976. Dispõe sobre a Vigilância Sanitária a que ficam sujeitos os Medicamentos, as Drogas, os Insumos Farmacêuticos e Correlatos, Cosméticos, Saneantes e outros Produtos, e dá outras Providências. Brasília, Publicado do Diário Oficial da União em 24 de setembro de 1976. Disponível em: <http://www.planalto.gov.br/ccivil_03/leis//6360.htm>. Acesso em: 15 jun. 2015.
} 
sem Ihe trazer benefício adicional, o seu custo não poderá ser mais caro ao já existente. Vê-se, portanto, que o registro do medicamento também é requisito que se coaduna à racionalização dos gastos públicos.

Contudo, saliente-se que essa regra não é absoluta, em face da permissão contida no diploma legal de $n^{\circ}$ 9.782, de 26 de janeiro de 1999, dada à ANVISA, a fim de que esta dispense o registro de medicamentos adquiridos por intermédio de organismos multilaterais internacionais, para uso de programas em saúde pública pelo Ministério da Saúde. ${ }^{41}$

Nos casos que envolvem uma decisão administrativa de não fornecer a prestação de saúde, recorre-se à adoção, no sistema brasileiro dos chamados PCDTs. A Administração Pública pode, assim, decidir não custear, no âmbito do SUS, um dado tratamento de saúde por entender que inexistem evidências científicas que autorizem a sua inclusão. Contudo, é premente a necessidade da atualização periódica dos protocolos existentes, bem como da criação de novas listas de medicamentos, de modo que não se pode admitir que os PCDTs sejam inquestionáveis, permitindo sua contestação judicial.

Nessa hipótese, pode ocorrer do SUS fornecer tratamento alternativo, bem como que não seja contemplado nenhum tratamento específico para determinada patologia. Inicialmente, a concessão de medicamentos não contidos nos PCDTs deve ser vista com cautela, pois, a priori, tende a contrariar 0 consenso científico. Ademais, nos casos em que a alternativa ofertada pela Rede Pública seja comprovadamente eficiente ao tratamento do paciente, a prestação contida no SUS deve ser privilegiada, em detrimento da requerida judicialmente. Todavia, provando o requerente a ineficácia do tratamento prestado pelo SUS ao seu caso concreto, fica ressalvada a possibilidade de concessão da medida pleiteada.

No que tange à concessão de tratamentos experimentais, firmou-se entendimento de que o Estado não pode ser condenado a fornecê-los, tendo em vista que fazem uso de drogas ainda não avaliadas ou não aprovadas, as quais se encontram em fase de pesquisa médica, devendo apenas ser empregadas em estudos clínicos. Essa situação, contudo, difere-se dos medicamentos que, inobstante possuírem registro na ANVISA, ainda não foram incorporados pelo SUS. Nesse caso, a mera argumentação da inexistência de PCDT não pode obstar a concessão da tutela pretendida. Todavia, as ações dessa natureza devem abarcar amplo lastro probatório, o que pode vir a impedir a concessão de medidas cautelares.

Aponta-se, ainda, para a necessidade de se promover alternativas que busquem solucionar extrajudicialmente os conflitos que surgem dentro da seara das prestações das ações e serviços de saúde. Convênios firmados entre

\footnotetext{
${ }^{41}$ BRASIL. Lei no 9.782, de 26 de janeiro de 1999. Define o Sistema Nacional de Vigilância Sanitária, cria a Agência Nacional de Vigilância Sanitária, e dá outras providências. Brasília, Publicado no Diário Oficial da União em 27 de janeiro de 1999. Disponível em: <http://www.planalto.gov.br/ ccivil_03/leis/l9782.htm>. Acesso em: 15 jun. 2015.
} 
Secretarias de Saúde, Procuradorias e Defensoria Pública, por exemplo, podem surtir efeitos positivos no sentido de minimizar as demandas que chegam ao judiciário, bem como denotá-las de essencialidade e uniformidade, pois, se eficientemente implantadas, deixariam ao julgamento desse Poder apenas as questões que não podem ser resolvidas na via administrativa.

Mostra-se, portanto, salutar à manutenção e ao desenvolvimento do SUS que sejam adotados parâmetros que conduzam a atuação do Judiciário no que concerne ao processo de judicialização da saúde, em especial no que tange ao fornecimento de medicamentos, em virtude da demonstração do grande impacto orçamentário promovido na seara da Assistência Farmacêutica. Nesse aspecto, somando-se às recomendações apontadas pelo STF, relembre-se o papel exercido pelo princípio da dignidade da pessoa humana, no sentido de determinar a existência de um mínimo existencial a ser garantido e efetivado pelos Poderes Públicos.

Desse modo, vê-se que o STF tem entendido pela fundamentalidade dos direitos sociais, e, consequentemente, pela sua aplicação imediata, reconhecendo que a Constituição elegeu um núcleo básico desses direitos, que goza de plena eficácia e podem ser exigidos judicialmente, quando caracterizada a omissão legislativa ou sua atuação ineficiente (proteção insuficiente). A mera alegação da falta de recursos não pode, portanto, servir de subterfúgio ao Poder Público, em clara demonstração de que os princípios orçamentários e o primado da separação dos poderes não podem superar 0 ideal da garantia e concretização dos direitos fundamentais no âmbito do Estado Democrático de Direito.

\section{CONCLUSÃO}

É fato que a Constituição de 1988 reconheceu a saúde como direito de todos e dever do Estado, a ser garantida mediante políticas sociais e econômicas. Isso não quer dizer que se tenha atribuído ao legislador infraconstitucional o papel de regulamentar todo o seu conteúdo material. Ao contrário, deve-se reconhecer que o constituinte originário tratou de assegurar um núcleo essencial desse direito, que se torna inviolável e intangível, não fazendo parte do âmbito da discricionariedade e conformação do legislador e do administrador público.

Todavia, não se pode olvidar de que a realização dos direitos sociais enquanto gênero - demanda uma atuação positiva por parte do Estado, a ser realizada por meio de políticas públicas, reconhecendo-se a necessidade de se promover a escolhas alocativas, seguindo-se a ordem da justiça distributiva, em razão da escassez dos recursos públicos diante da infinidade de prestações que podem vir a ser pleiteadas com base naqueles direitos.

Nesse contexto, surgem limitações fáticas e jurídicas à realização dos direitos sociais, em especial do direito à saúde, o qual, destarte, restaria condicionado ao postulado da reserva do possível. Viu-se, contudo, que essa argumentação não pode prevalecer de forma absoluta, só merecendo acolhida quando devidamente provada à inexistência de recursos a serem aplicados na 
promoção e/ou recuperação da saúde, desde que demonstrado que os gastos realizados nessa seara se deram em conformidade com o estabelecido pela Constituição.

Outrossim, a aplicação da reserva do possível deve, ainda, ser sopesada pelo que se convencionou chamar de mínimo existencial. Engendra-se o entendimento de que esse mínimo deve corresponder ao núcleo essencial traçado na Constituição vigente, e sua aferição deve se dar caso a caso, em face da análise concreta das condições sociais, econômicas e culturais que envolvem o indivíduo e o meio no qual ele se insere.

Assim, diante do reconhecimento do direito subjetivo público ao mínimo legal à saúde, reconhece-se como legítima a atuação do cidadão na luta pela sua concretização em termos práticos, recorrendo se preciso for ao Poder Judiciário, órgão imprescindível à sua efetivação quando caracterizado ato ilegal ou abuso do Legislativo e/ou do Executivo, em face de sua omissão ou da proteção insuficiente atribuída ao respectivo direito.

Contatou-se a indispensabilidade da atuação do Poder Judiciário quando se requer, através das ações de saúde, tratamento já enquadrado em política pública no âmbito do SUS, que estabelecem prestações além do núcleo essencial constitucional. Nesses casos, viu-se que o ativismo além de assegurar o cumprimento de política já implementada utiliza parâmetros seguros quando à concessão de tutelas individuais que pretendem a condenação do Estado ao fornecimento de medicamentos, objetivando minimizar os efeitos negativos gerados à Política Nacional de Assistência Farmacêutica por esse tipo de demanda.

Resta clarividente que em se tratando de fornecimento de medicamentos, incumbe ao magistrado um papel proativo na solução desse tipo de conflito, cuja urgência suscita uma apreciação equânime e célere, posto assegurar o próprio direito à vida. Ciente de sua relevância é crucial que todos os membros da sociedade atuem como verdadeiros fiscais do interesse público, agindo nas demandas individuais e, bem como, em ações coletivas sempre na perspectiva de defesa da Dignidade da Pessoa Humana, salvaguardando as políticas públicas já existentes, e buscando a chancela de decisões em que se beneficiam um número maior de indivíduos com o menor impacto orçamentário possível.

Do exposto, verificou-se que a judicialização não pode vir a representar uma afronta ao Princípio da Separação dos Poderes, ao orçamento ou ao postulado da reserva do possível, influindo negativamente na implantação de Políticas Públicas, todavia, se reconhece o papel legítimo atribuído ao Judiciário de efetivar os Direitos Fundamentais, notadamente o Direito à Saúde, quando da omissão dos demais Poderes constituídos, como forma de consignar a devida tutela ao mínimo existencial de cada indivíduo, em prol de sua dignidade, enquanto valor máximo a ser perseguido nos quadros do Estado Constitucional Democrático. 


\section{REFERÊNCIAS}

BARCELLOS, Ana Paula de. Conclusão: o mínimo existencial como núcleo sindicável da dignidade da pessoa humana. Uma proposta de concretização a partir da Constituição de 1988. In: A Eficácia Jurídica dos Princípios Constitucionais: o princípio da dignidade humana. 3. ed., Rio de Janeiro: Renovar, 2011.

BARCELLOS, Ana Paula de. O Direito a Prestações de Saúde: complexidades, mínimo existencial e o valor das abordagens coletiva e abstrata. In: Revista da Defensoria Pública, ano 1, no 1, p. 133-178. Disponível em: <http://www.defensoria.sp.gov.br/dpesp/ repositorio/20/documentos/outros/Revista\%20n\%C2\%BA\%201\%20Volume\%201.pdf>. Acesso em: 15 jun. 2015.

BARROSO, Luís Roberto. Da Falta de Efetividade à Judicialização Excessiva: direito à saúde, fornecimento gratuito de medicamentos e parâmetros para a atuação judicial. In: Revista Jurídica UNIJUS, Minas Gerais, v. 11, n 15, p. 13-38, nov. 2008. Disponível em: <http://www.uniube.br/publicacoes/unijus/arquivos/unijus_15.pdf>. Acesso em: 15 jun. 2015. BARROSO, Luís Roberto. Neoconstitucionalismo e Constitucionalização do Direito (o triunfo tardio do Direito Constitucional no Brasil). In: Revista Eletrônica sobre a Reforma do Estado (RERE), Instituto Brasileiro de Direito Público, n 9, mar./abr./maio, Salvador/ Bahia, 2007, p. 03. Disponível em: <http://www.direitodoestado.com/revista/RERE-9MAR\%C7O-2007-LUIZ\%2OROBERTO\%20BARROSO.pdf>. Acesso em: 15 jun. 2015.

BORGES, Danielle da Costa Leite; UGÁ, Maria Alicia Dominguez. As Ações Individuais para o Fornecimento de Medicamentos no Âmbito do SUS: características dos conflitos e limites para a atuação judicial. In: Revista de Direito Sanitário, São Paulo, v. 10, no 1 , p. 13-38, mar./jul. 2009. Disponível em: <http://www.revistasusp.sibi.usp.br/pdf/rdisan/ v10n1/02.pdf>. Acesso em: 15 jun. 2015.

BRASIL. Lei $n^{\circ} 6.360$, de 23 de setembro de 1976. Dispõe sobre a Vigilância Sanitária a que ficam sujeitos os Medicamentos, as Drogas, os Insumos Farmacêuticos e Correlatos, Cosméticos, Saneantes e outros Produtos, e dá outras Providências. Brasília, Publicado do Diário Oficial da União em 24 de setembro de 1976. Disponível em: <http://www.planalto.gov.br/ccivil_03/leis/l6360.htm>. Acesso em: 15 jun. 2015.

. Lei $n^{\circ} 8.080$, de 19 de setembro de 1990. Dispõe sobre as condições para a promoção, proteção e recuperação da saúde, a organização e o funcionamento dos serviços correspondentes e dá outras providências. Disponível em: <http://www. planalto. gov.br/ccivil_03/leis//8080.htm>. Acesso em: 15 jun. 2015.

Lei $n^{\circ}$ 9.782, de 26 de janeiro de 1999. Define o Sistema Nacional de Vigilância Sanitária, cria a Agência Nacional de Vigilância Sanitária, e dá outras providências. Brasília, Publicado no Diário Oficial da União em 27 de janeiro de 1999. Disponível em: <http://www.planalto.gov.br/ccivil_03/leis/l9782.htm>. Acesso em: 15 jun. 2015.

Supremo Tribunal de Justiça. Recurso Especial $n^{0} 716.512 .1^{a}$ Turma. Ministro Relator: Luiz Fux. Publicado no Diário de Justiça em 14 de maio de 2005. Disponível em: <http://www.mp.rs.gov.br/infancia/jurisp/idt267.htm>. Acesso em: 15 jun. 2015.

Supremo Tribunal Federal. Agravo Regimental no Recurso Extraordinário ${ }^{\circ}$ 271.286-RS. Agravante: Município de Porto Alegre. Agravada: Diná Rosa Vieira. Relator: Ministro Celso de Mello. Brasília, 12 de setembro de 2000. Publicado no Diário de Justiça Eletrônico em 24 de novembro de 2000. Disponível em: <http://redir.stf.jus.br/ paginadorpub/paginador.jsp?docTP=AC\&docID=335538>. Acesso em: 15 jun. 2015.

. Supremo Tribunal Federal. Agravo Regimental na Suspensão de Tutela Antecipada $\mathrm{n}^{\circ}$ 175-CE. Agravante: União. Agravados: Ministério Público Federal, 
Município de Fortaleza e Clarice Abreu de Castro Neves. Relator: Ministro Gilmar Mendes. Brasília, 17 de março de 2010. Publicado no Diário de Justiça Eletrônico em 30 de abril de 2010. Disponível em: <http://redir.stf.jus.br/paginadorpub/paginador.jsp? docTP=AC\&docID=610255>. Acesso em: 15 jun. 2015.

. Supremo Tribunal Federal. Arguição de Descumprimento de Preceito Fundamental n 45. ARGDO: Presidente da República. ARGTE: Partido da Social Democracia Brasileira. Relator: Ministro Celso de Mello. Publicada em 04 de janeiro de 2004. Disponível em: <http://www.stf.jus.br/portal/jurisprudencia/listarJurisprudencia.asp?s1=\%28ADPF\%24\%2 ESCLA\%2E+E+45\%2ENUME\%2E\%29\&base=basePresidencia>. Acesso em: 15 jun. 2015. CARLINI, Angélica. et al. O CNJ e os Desafios da Efetivação do Direito à Saúde. Belo Horizonte: Fórum, 2011.

CARVALHO FILHO, José dos Santos. Manual de Direito Administrativo. 22. ed., rev. ampl. e atual. Rio de Janeiro: Lúmen Juris, 2009.

CHIEFFI, Ana Luiza; BARATA, Rita Barradas. Judicialização da Política Pública de Assistência Farmacêutica e Equidade (sic). In: Caderno de Saúde Pública, Rio de Janeiro, v. 25, no 8, p. 1839-1849, ago. 2009. Disponível em: <http://www.scielo.br/pdf/ csp/v25n8/20.pdf>. Acesso em: 15 jun. 2015.

DUARTE, Bento Herculano; GABURRI, Fernando. (Coords.) A Fazenda Pública à Luz da Atual Jurisprudência dos Tribunais Brasileiros. Curitiba: Juruá, 2011.

KELBERT, Fabiana Okchstein. Os Direitos Fundamentais, seus Custos e as Dimensões da Reserva do Possível: análise e possibilidades de superação no âmbito da concretização dos direitos sociais. In: Reserva do Possível e a Efetividade dos Direitos Sociais no Direito Brasileiro. Porto Alegre: Livraria do Advogado, 2011.

MARINONI, Luiz Guilherme. Processo de Conhecimento. 10. ed., São Paulo: Revista dos Tribunais, 2012.

MEDEIROS, Fabrício Juliano Mendes. O Ativismo Judicial e o Direito à Saúde. Belo Horizonte: Fórum, 2011.

NUNES, Antônio José Avelãs; SCAFF, Fernando Facury. Os Tribunais e o Direito à Saúde. Porto Alegre: Livraria do Advogado Editora, 2011.

PEPE, Vera Lúcia Edais, et al. A Judicialização da Saúde e os Novos Desafios da Gestão da Assistência Farmacêutica. In: Ciência e Saúde Coletiva, v. 15, no 5, p. 2405-2414, ago. 2010. Disponível em: <http://www.scielo.br/scielo.php?script=sci_arttext\&pid= S1413-81232010000500015>. Acesso em: 15 jun. 2015.

QUEIROZ, Cristina. O Princípio da Não Reversibilidade dos Direitos Fundamentais Sociais. In: O Princípio da Não Reversibilidade dos Direitos Fundamentais: princípios dogmáticos e prática jurisprudencial. Coimbra: Coimbra Editora, 2006.

SARLET, Ingo Wolfgang; FIGUEIREDO, Mariana Filchtiner. Reserva do Possível, Mínimo Existencial e Direito à Saúde: algumas aproximações. In: Revista da Defensoria Pública, ano 1, $\mathrm{n}^{\circ}$ 1, p. 179-234. Disponível em: <http://www.defensoria.sp.gov.br/ dpesp/repositorio/ 20/documentos/outros/Revista\%20n\%C2\%BA\%201\%20Volume\%201.pdf>. Acesso em 15 jun. 2015.

SARMENTO, Daniel. A Ponderação de Interesses na Constituição. Rio de Janeiro: Lúmen Juris, 2000.

SBRISSIA, Larissa Fischer. A Efetividade dos Direitos Fundamentais Sociais Frente à Reserva do Possível. Disponível em: <http://www.unibrasil.com.br/arquivos/direito/20092/ larissa-fischer-sbrissia.pdf>. Acesso em: 15 jun. 2015. 